\title{
Evaluation of Sex Sensitivity in Local Lymph Node Assay Using Acephate and $\alpha$ - Hexylcinnamaldehyde
}

\author{
Dalal V ${ }^{\mathrm{a}}$., Chhimwal $\mathrm{R}^{\mathrm{a}}$., Verma $\mathrm{R}^{\mathrm{a}}$ and Suresh $\mathrm{B}^{\mathrm{b}}$. \\ ${ }^{a}$ Jai Research Foundation, Gujarat, India \\ ${ }^{b}$ Department of Zoology, Faculty of Science, The M.S. University of Baroda, Vadodara, Gujarat, India
}

\begin{abstract}
The current OECD Test Guideline for the conduct of the Local Lymph Node Assay (LLNA) recommends the use of only female mice for the assessment of skin sensitization potential for a given chemical. The NIH publication $N^{\circ}$ 99-4494 recommends that only female CBA mice be used, as they reportedly develop a stronger contact dermatitis response when compared to males however if male to be used, systematic studies evaluating potential sex differences should be conducted. Moreover, males were reported to display a larger variation in response due to a greater tendency to fight and to be involved in 'social ranking' behavior when group housed. However, there are several advantages to consider with the inclusion of male mice in LLNA testing including a more refined and responsible use of animals. Therefore, to begin to systematically assess the appropriateness of using male mice in the LLNA a comparative guideline study was conducted with individual housing of mice using a non-sensitizer and a sensitizer viz., Acephate $97 \mathrm{DF}$ and $\alpha$-hexylcinnamaldehyde (HCA) respectively. We have conducted an in-house study using a vehicle (dimethyl formamide) that is recommended by OECD 429 for the testing of mixtures in the LLNA for assessing skin sensitisation. We conducted the test according to the methods described by OECD 429 (Skin Sensitization: Local Lymph Node Assay). One common pesticide formulation, Acephate $97 \mathrm{DF}$ and one known skin sensitizer - HCA, were each applied to the dorsum of both ears (25 $\mu \mathrm{L}$ per ear) of groups of 5 female CBA/J mice (male and female). Acephate $97 \mathrm{DF}$ was applied at 3 separate concentrations and one concentration for HCA for 3 consecutive days (days 0,1 and 2). A further group was given the vehicle (dimethyl formamide), alone. On day 5, all mice were injected intravenously (tail vein) with approximately $20( \pm 1) \mu C i$ of tritiated methyl thymidine. Five hours post-administration the uptake of 3 H-thymidine into the auricular (local) lymph nodes draining the site of chemical application was measured in order to assess the proliferative response of the lymph node. The DPM values were measured individually for each mouse. Stimulation Index (SI Value) was calculated and are given below:
\end{abstract}

\begin{tabular}{|c|c|c|c|c|}
\cline { 2 - 4 } \multicolumn{1}{c|}{} & (conc) SI & (conc) SI & (conc) SI & $\begin{array}{c}\text { Historical rage of } \\
\text { Female mice } \\
\text { (in JRF) }\end{array}$ \\
\hline HCA (Male) & $(25 \%) \mathbf{4 . 3 1}$ & - & - & \multirow{3}{*}{$\mathbf{3 . 8 9}$ to 12.25 } \\
\hline HCA (Female) & $(25 \%) \mathbf{5 . 4 4}$ & - & - & - \\
\hline Acephate 97 DF (Male) & $(10 \%) \mathbf{1 . 1 6}$ & $(25 \%) \mathbf{1 . 5 8}$ & $(50 \%) \mathbf{1 . 5 9}$ & - \\
\hline Acephate 97 DF (Female & $(10 \%) \mathbf{1 . 3 9}$ & $(25 \%) \mathbf{1 . 5 5}$ & $(50 \%) \mathbf{1 . 5 6}$ & - \\
\hline
\end{tabular}

Values shown in bold have a SI three or more times greater than the control (Control SI = 1) and are considered to have the potential to cause skin sensitisation.

The results obtained in the present study for HCA are comparable with the Historical Control Data of Laboratory (Jai Research Foundation).

\section{Objective}

The mouse local lymph node assay (LLNA) is an accepted test for evaluating the dermal sensitising potential of chemicals. The method is described in the OECD guideline 429: Skin Sensitization: Local Lymph Node Assay; however, limited guidance is given on its use for the testing of formulations and mixtures. At JRF, to expand our LLNA capabilities to include the testing of formulations and mixtures, we conducted an in-house validation study using male and female mice. We conducted a test to check the reliability, sensitivity and reproducibility of the method using HCA as positive control and made a comparison with the results of positive control data obtained from our laboratories.

Test Materials and Vehicle

Test Material

a-Hexylcinnamaldehyde (HCA)

\section{Materials \& Methods}

Purity Source

85\% Sigma-Aldrich Chemie $\mathrm{GmbH}$ 
Test Animals

CBA/J male and female mice (9 to 10 weeks old) comprising 5 females per groups (source: Animal Breeding Facility, JRF) were used for study. Mice were housed individually. Feed (Teklad Certified Global High Fiber Rat/Mice feed manufactured by Harlan, USA, was provided ad libitum.) and water (UV sterilised water (Kent Reverse Osmosis water filtration system) was provided ad libitum.) was provided ad libitum. Environmental conditions were maintained as per international requirements.

Experimental Design

Dimethyl formamide (DMF) was used as the vehicle. This vehicle was recommended by the OECD 429. One known non skin sensitizer pesticide formulation, Acephate $97 \mathrm{DF}$ and one known skin sensitizer Hexylcinnamaldehyde (HCA) were selected for the test. The dose levels were based on preliminary assay for Acephate 97 DF.

The study design followed that recommended by OECD $429^{1}$ and the following dose regimen was selected for the main study.

Treatment Procedure

Animals were treated topically for three consecutive days (days 0,1 and 2) on the dorsal surface of both ears $(25 \mu \mathrm{L} / \mathrm{ear})$ using a calibrated micropipette. No treatment was applied on days 3 and 4 . On day 5, all mice were injected intravenously (tail vein) with $250 \mu \mathrm{L}$ of sterile phosphate buffered saline (PBS) containing approximately $20( \pm 1) \mu \mathrm{Ci}$ of tritiated methyl thymidine (Board of Radiation and Isotope Technology, DAE, India). Five hours post-injection of $3 \mathrm{H}$-methyl thymidine, the animals were euthanized and the draining auricular (local) lymph node from both ears of each animal was excised and collected into PBS.

A single cell suspension of lymph node cells (LNC) was prepared for each mouse by gentle mechanical disaggregation through 200-210 $\mu \mathrm{m}$-mesh stainless steel gauze with the plunger of the syringe. The gauze was washed with PBS into the base of a petri dish and the single cell suspension was transferred into a centrifuge tube and made up to $10 \mathrm{~mL}$ with PBS and centrifuged at approximately 190 to $200 \mathrm{~g}$ for 10 minutes at $4( \pm 2)$ ${ }^{\circ} \mathrm{C}$. This procedure was performed twice. After the final wash each supernatant was removed leaving just a small volume of supernatant and then re-suspended with $3 \mathrm{~mL}$ of $5 \%$ trichloroacetic acid (TCA) and kept for precipitation for 18 at $4( \pm 2){ }^{\circ} \mathrm{C}$. Thereafter each precipitate was recovered by centrifugation, the supernatant was removed and $1 \mathrm{~mL}$ of $5 \%$ TCA.was added. Each precipitate was transferred to a scintillation vial containing (Hionic flour) scintillation fluid.

The uptake of $3 \mathrm{H}$-thymidine into the auricular (local) lymph nodes draining the site of chemical application was measured using a $\beta$-scintillation counter to assess the lymph node proliferative response in disintegrations per minutes $(\mathrm{dpm})$.

Parameters as such body weight and ear thickness measurement also considered for evaluation. Evaluation of Results

The test item was not regarded as a skin sensitiser ifas the SI for a dose group is $\leq 3$ together with consideration of a dose-response relationship. given below.

$\mathrm{EC}_{3}{ }^{2}$ value (theoretical concentration resulting in a SI value of 3) was calculated using the equation

$$
\mathrm{EC}_{3}=\mathrm{c}+[(3-\mathrm{d}) /(\mathrm{b}-\mathrm{d})] \times(\mathrm{a}-\mathrm{c})
$$

Where $\mathrm{a}=$ the lowest concentration giving stimulation index $>3 ; \mathrm{b}=$ the actual stimulation index caused by $\mathrm{a} ; \mathrm{c}=$ the highest concentration failing to produce a stimulation index of 3 ; and $\mathrm{d}=$ the actual stimulation index caused by c.

Categorization of contact allergens on the basis of relative skin sensitization potency, is conducted using EC3

\footnotetext{
${ }^{1}$ OECD N ${ }^{\circ} 429$, "Skin Sensitisation: Local Lymph Node Assay". The Organisation for Economic Co-operation and Development (OECD) Guideline for Testing of Chemicals, adopted by the Council on July 22, 2010.

${ }^{2}$ Basketter, D.A., Lea, L.J., Dickens, A., Briggs, D., Pate, I., Dearman, R.J., and Kimber, I. (1999): A comparison of statistical approaches to the deviation of $\mathrm{EC}_{3}$ values from local lymph node assay dose responses. J. Appl. Toxicol. 19, 261-266.
} 
values derived from the LLNA ${ }^{3}$.

Any test material that produces a SI $<3$ in the LLNA is considered negative for contact sensitization potential and therefore, an EC3 is not determined.

$\begin{array}{ll}\mathrm{EC}_{3} \text { value } & \text { Category } \\ <0.1 \% & \text { extreme sensitizer } \\ 0.1-<1 \% & \text { strong sensitizer } \\ 1-<10 \% & \text { moderate sensitizer } \\ 10-100 \% & \text { weak sensitizer }\end{array}$

Body weight and radioactive disintegrations per minute (dpm) were subjected to Bartlett's test to meet the homogeneity of variance before conducting Analysis of Variance (ANOVA) and Dunnett's t-test to assess statistical significance from the control.

Body Weight

\section{Results}

The mean body weight of treatment group animals was comparable to that of the control group.

Local Irritation Response and Ear Thickness Percent Change

No erythema was observed in any treated mice at 10\%, 25\% and 50\% (w/v) of Acephate $97 \mathrm{DF}$ on day 0 to day 5 . Very slight erythema (barely perceptible) was observed in dose group of $25 \%$ HCA (on days 1 to 4 ) in all mice ( $5 / 5$ male mice and $5 / 5$ female mice).

Ear thickness measurements showed much individual variation but revealed maximum increases on day 2 at $25 \%$ concentrationof $\mathrm{HCA}$; around $18 \%$. Acephate $97 \mathrm{DF}$ treated group shows 8 to $12 \%$ increases on day 2 at $10 \%, 25 \%$ and $50 \%(\mathrm{w} / \mathrm{v})$ concentrations.

Summary of Ear Thickness Percent Change

Male

\begin{tabular}{|c|c|c|c|c|c|c|}
\hline \multirow{3}{*}{ Group $\mathrm{N}^{\circ}$} & \multirow{3}{*}{$\begin{array}{c}\text { Dose } \\
\text { Concentration (\%) }\end{array}$} & \multirow{3}{*}{$\begin{array}{l}\mathrm{N}^{\circ} \text { of } \\
\text { Mice } \\
\text { Used }\end{array}$} & \multicolumn{4}{|c|}{ Mean Ear Thickness (Percent Change) } \\
\hline & & & \multicolumn{2}{|c|}{$\begin{array}{l}\text { Left Ear Thickness } \\
\text { (\% Change) }\end{array}$} & \multicolumn{2}{|c|}{$\begin{array}{l}\text { Right Ear Thickness } \\
\text { (\% Change) }\end{array}$} \\
\hline & & & On Day 2 & On Day 5 & On Day 2 & On Day 5 \\
\hline G1 & Control (DMF) & 5 & $\begin{array}{c}4.008 \\
\pm \\
0.681\end{array}$ & $\begin{array}{c}2.915 \\
\pm \\
0.443\end{array}$ & $\begin{array}{c}3.970 \\
\pm \\
0.671\end{array}$ & $\begin{array}{c}3.036 \\
\pm \\
0.579\end{array}$ \\
\hline G2 & $10 \%$ Acephate $97 \mathrm{DF}(\mathrm{w} / \mathrm{v})$ in DMF & 5 & $\begin{array}{c}7.920 \\
\pm \\
1.350 \\
\end{array}$ & $\begin{array}{c}5.226 \\
\pm \\
0.791 \\
\end{array}$ & $\begin{array}{c}8.271 \\
\pm \\
1.323 \\
\end{array}$ & $\begin{array}{c}4.932 \\
\pm \\
0.675 \\
\end{array}$ \\
\hline G3 & $25 \%$ Acephate $97 \mathrm{DF}(\mathrm{w} / \mathrm{v})$ in DMF & 5 & $\begin{array}{c}10.833 \\
\pm \\
0.399 \\
\end{array}$ & $\begin{array}{c}7.918 \\
\pm \\
0.542 \\
\end{array}$ & $\begin{array}{c}10.984 \\
\pm \\
0.307\end{array}$ & $\begin{array}{c}7.687 \\
\pm \\
0.633 \\
\end{array}$ \\
\hline G4 & $50 \%$ Acephate $97 \mathrm{DF}(\mathrm{w} / \mathrm{v})$ in DMF & 5 & $\begin{array}{c}14.823 \\
\pm \\
0.435 \\
\end{array}$ & $\begin{array}{c}11.782 \\
\pm \\
1.158 \\
\end{array}$ & $\begin{array}{c}14.673 \\
\pm \\
0.533\end{array}$ & $\begin{array}{c}11.023 \\
\pm \\
1.741 \\
\end{array}$ \\
\hline G5 & $25 \% \mathrm{HCA}(\mathrm{w} / \mathrm{v})$ in $\mathrm{DMF}$ & 5 & $\begin{array}{c}17.768 \\
\pm \\
0.810 \\
\end{array}$ & $\begin{array}{c}14.689 \\
\pm \\
0.848 \\
\end{array}$ & $\begin{array}{c}18.016 \\
\pm \\
0.746\end{array}$ & $\begin{array}{c}14.421 \\
\pm \\
0.869 \\
\end{array}$ \\
\hline
\end{tabular}

Note: Values are in mean \pm standard deviation.

\footnotetext{
${ }^{3}$ Kimber I., Basketter, D. A., Butler M., Gamer A., Garrigue J.L., Gerberick, G.F., Newsome, C., Steiling, W., Vohr, H.W. (2003). Classification of Contact Allergens According to Potency: Proposal. Fd. Chem. Toxicol. 41, 1799-1809.
} 
Evaluation of Sex Sensitivity in Local Lymph Node Assay Using Acephate and $\alpha$ -

Female

\begin{tabular}{|c|c|c|c|c|c|c|}
\hline \multirow{3}{*}{ Group $\mathrm{N}^{\circ}$} & \multirow{3}{*}{$\begin{array}{c}\text { Dose } \\
\text { Concentration (\%) }\end{array}$} & \multirow{3}{*}{$\begin{array}{l}\mathrm{N}^{\circ} \text { of } \\
\text { Mice } \\
\text { Used }\end{array}$} & \multicolumn{4}{|c|}{ Mean Ear Thickness (Percent Change) } \\
\hline & & & \multicolumn{2}{|c|}{$\begin{array}{l}\text { Left Ear Thickness } \\
\text { (\% Change) }\end{array}$} & \multicolumn{2}{|c|}{$\begin{array}{l}\text { Right Ear Thickness } \\
\text { (\% Change) }\end{array}$} \\
\hline & & & On Day 2 & On Day 5 & On Day 2 & On Day 5 \\
\hline & & & 4.145 & 2.262 & 4.459 & 2.024 \\
\hline G6 & Control (DMF) & 5 & $\stackrel{ \pm}{ \pm}$ & $\begin{array}{c} \pm \\
0.491\end{array}$ & $\stackrel{\stackrel{ \pm}{561}}{0.561}$ & $\stackrel{ \pm}{ \pm}$ \\
\hline G7 & $10 \%$ Acephate $97 \mathrm{DF}(\mathrm{w} / \mathrm{v})$ in DMF & 5 & $\begin{array}{c}7.384 \\
\pm \\
0.561\end{array}$ & $\begin{array}{c}4.224 \\
\pm \\
0.723\end{array}$ & $\begin{array}{c}7.965 \\
\pm \\
1.436\end{array}$ & $\begin{array}{c}4.302 \\
\pm \\
0.222\end{array}$ \\
\hline G8 & $25 \%$ Acephate $97 \mathrm{DF}(\mathrm{w} / \mathrm{v})$ in DMF & 5 & $\begin{array}{c}11.020 \\
\pm \\
0.939\end{array}$ & $\begin{array}{c}8.316 \\
\pm \\
0.438\end{array}$ & $\begin{array}{c}11.333 \\
\pm \\
2.270\end{array}$ & $\begin{array}{c}8.129 \\
\pm \\
0.656\end{array}$ \\
\hline G9 & $50 \%$ Acephate $97 \mathrm{DF}(\mathrm{w} / \mathrm{v})$ in DMF & 5 & $\begin{array}{c}15.017 \\
\pm \\
0.982\end{array}$ & $\begin{array}{c}10.799 \\
\pm \\
0.651\end{array}$ & $\begin{array}{c}15.106 \\
\pm \\
1.521\end{array}$ & $\begin{array}{c}10.324 \\
\pm \\
0.464\end{array}$ \\
\hline G10 & $25 \% \mathrm{HCA}(\mathrm{w} / \mathrm{v})$ in DMF & 5 & $\begin{array}{c}18.911 \\
\pm \\
0.795\end{array}$ & $\begin{array}{c}14.248 \\
\pm \\
0.452\end{array}$ & $\begin{array}{c}18.861 \\
\pm \\
0.976\end{array}$ & $\begin{array}{c}14.141 \\
\pm \\
0.476\end{array}$ \\
\hline
\end{tabular}

Note: Values are in mean \pm standard deviation.

Mean of Left and Right Ear Thickness (Percent Change)

\begin{tabular}{|c|c|c|c|c|c|}
\hline \multirow{2}{*}{$\begin{array}{c}\text { Dose } \\
\text { Concentration (\%) }\end{array}$} & \multirow{2}{*}{$\begin{array}{c}\mathrm{N}^{\circ} \text { of } \\
\text { Mice }\end{array}$} & \multicolumn{4}{|c|}{ Mean Ear Thickness (Percent Change) } \\
\cline { 3 - 6 } & Used & On Day 2 & On Day 5 & On Day 2 & On Day 5 \\
\hline Control (DMF) & 5 & 3.989 & 2.976 & 4.302 & 2.143 \\
\hline $10 \%$ Acephate 97 DF (w/v) in DMF & 5 & 8.096 & 5.079 & 7.675 & 4.263 \\
\hline $25 \%$ Acephate 97 DF (w/v) in DMF & 5 & 10.909 & 7.803 & 15.062 & 10.562 \\
\hline $50 \%$ Acephate 97 DF (w/v) in DMF & 5 & 14.748 & 11.403 & 18.886 & 14.195 \\
\hline $25 \%$ HCA (w/v) in DMF & 5 & 17.892 & 14.555 & 4.302 & 2.143 \\
\hline
\end{tabular}

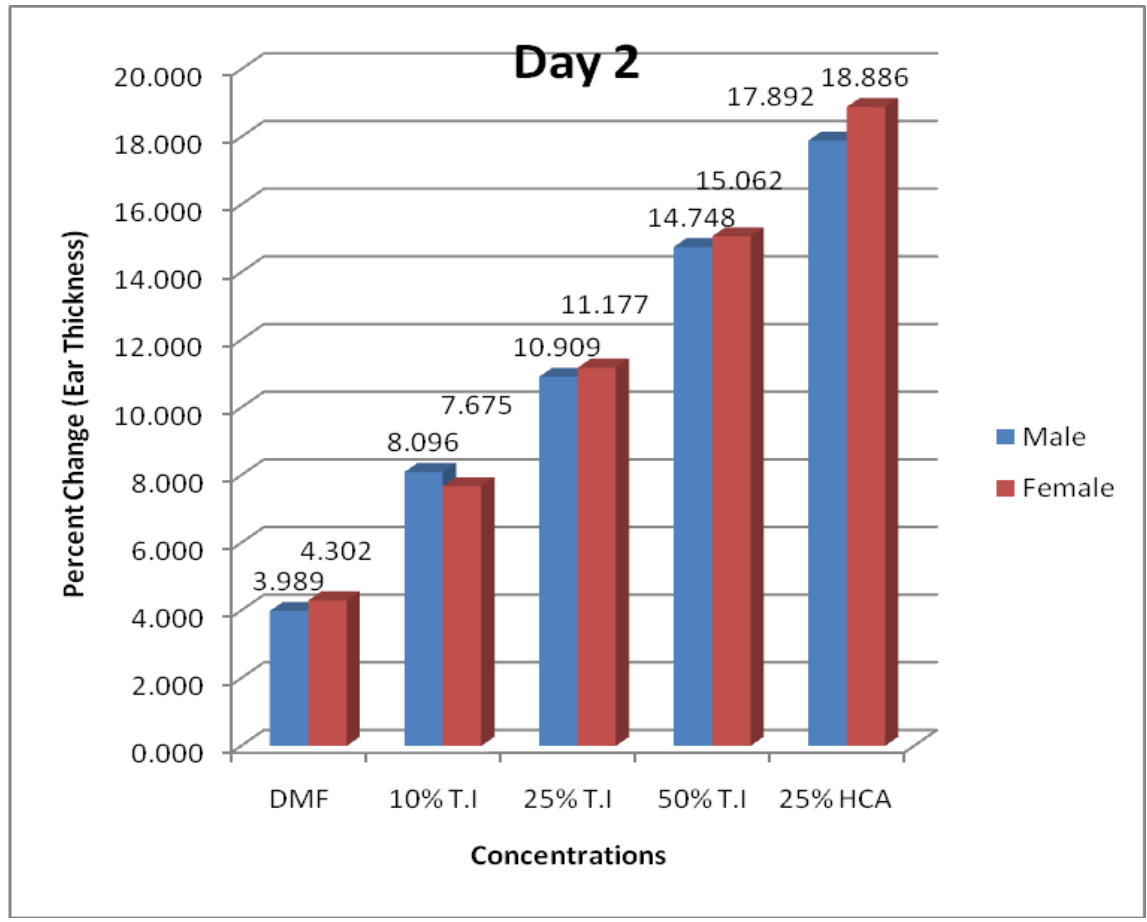




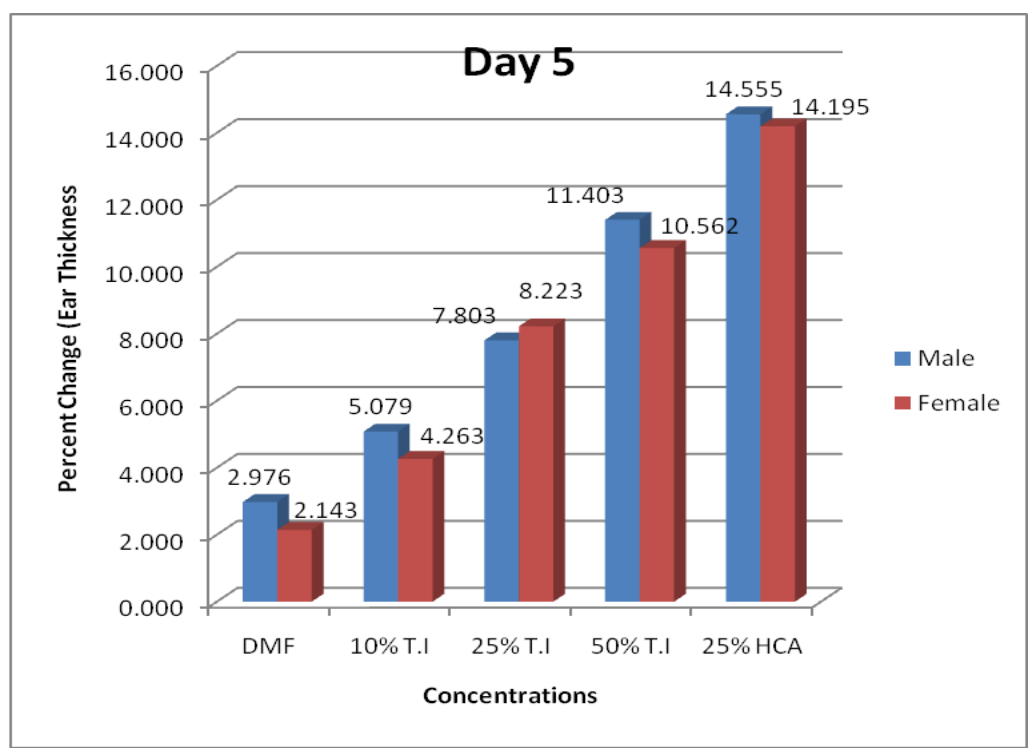

DPM and SI Value

DPM value observed at all the treatment groups of Acephate 97 DF statistically insignificant and in dose dependent manner for male as well as female mice. DPM value of HCA treated groups statistically significant in male as well as female mice.

Male Mice:

\begin{tabular}{|c|c|c|c|c|}
\hline Group N & $\begin{array}{c}\text { Dose Concentration } \\
(\%)\end{array}$ & $\begin{array}{c}\mathrm{N}^{\circ} \text { of Mice } \\
\text { Used }\end{array}$ & Group Mean DPM & Stimulation Index (SI) \\
\hline $\mathrm{G} 1$ & Control (DMF) & 5 & $376.30 \pm 88.64$ & 1.00 \\
\hline $\mathrm{G} 2$ & $\begin{array}{c}10 \% \text { Acephate 97 } \\
\text { DF (w/v) in DMF }\end{array}$ & 5 & $435.20 \pm 121.86$ & 1.16 \\
\hline $\mathrm{G} 3$ & $\begin{array}{l}25 \% \text { Acephate 97 } \\
\text { DF (w/v) in DMF }\end{array}$ & 5 & $593.60 \pm 183.83$ & 1.59 \\
\hline $\mathrm{G} 4$ & $\begin{array}{l}50 \% \text { Acephate 97 } \\
\text { DF (w/v) in DMF }\end{array}$ & 5 & $599.90 \pm 251.29$ & 4.31 \\
\hline $\mathrm{G} 5$ & $\begin{array}{c}25 \% \text { HCA (w/v) in } \\
\text { DMF }\end{array}$ & 5 & $1623.20 \pm 499.89 *$ & \\
\hline
\end{tabular}

Female Mice:

\begin{tabular}{|c|c|c|c|c|}
\hline Group $\mathrm{N}^{\circ}$ & $\begin{array}{c}\text { Dose } \\
\text { Concentration } \\
(\%)\end{array}$ & $\begin{array}{c}\mathrm{N}^{\circ} \text { of } \\
\text { Mice } \\
\text { Used }\end{array}$ & Group Mean DPM & Stimulation Index (SI) \\
\hline $\mathrm{G} 1$ & DMF & 5 & $493.10 \pm 160.28$ & 1.00 \\
\hline $\mathrm{G} 2$ & $\begin{array}{c}10 \% \text { Acephate } \\
97 \mathrm{DF}\end{array}$ & 5 & $683.38 \pm 267.31$ & 1.39 \\
\hline $\mathrm{G} 3$ & $\begin{array}{c}25 \% \text { Acephate } \\
97 \mathrm{DF}\end{array}$ & 5 & $762.60 \pm 380.01$ & 1.55 \\
\hline $\mathrm{G} 4$ & $\begin{array}{c}50 \% \text { Acephate } \\
97 \mathrm{DF}\end{array}$ & 5 & $770.70 \pm 321.69$ & 1.56 \\
\hline $\mathrm{G} 5$ & $25 \%$ HCA & 5 & $2680.90 \pm 390.50^{*}$ & 5.44 \\
\hline
\end{tabular}




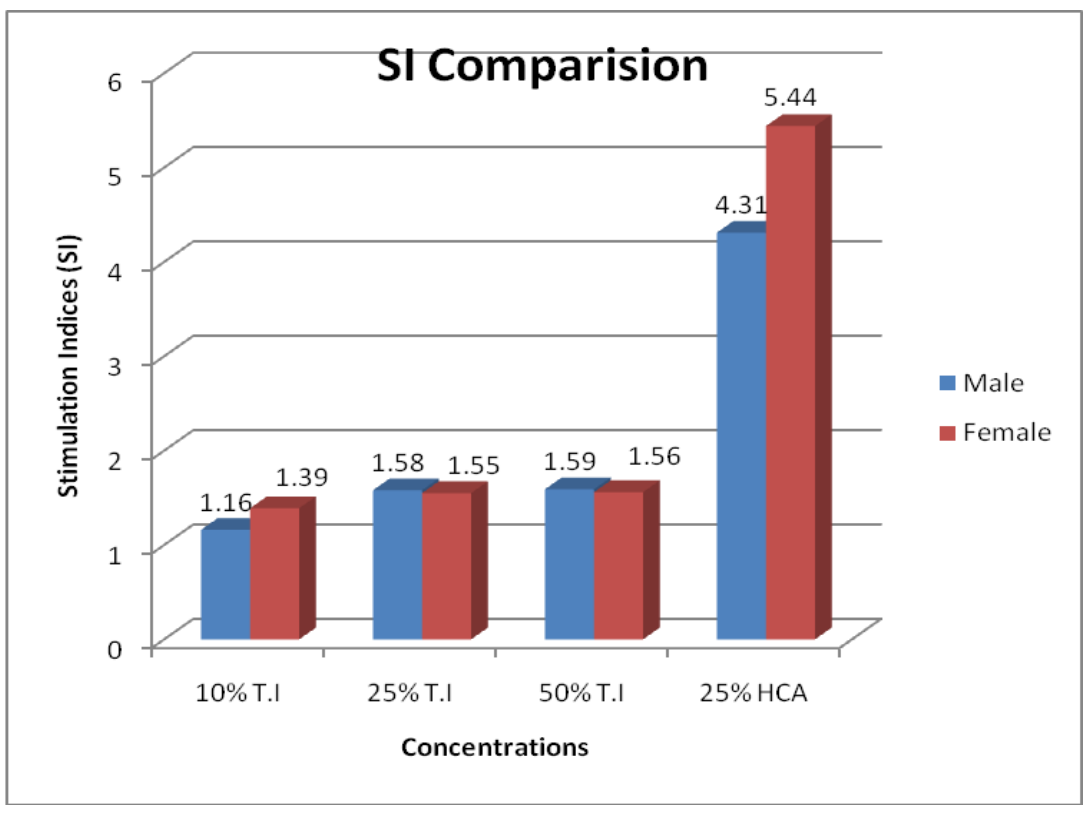

\section{Interpretation Of Results}

Based on the SI value, HCA is categorized as weak sensitizers. SI for the three Acephate $97 \mathrm{DF}$ treatment groups were 1.16, 1.58 and 1.59 for male and 1.39, 1.55 and 1.56 for females, respectively and SI for the HCA treated group were 4.31 for male and 5.44 for females. The SI of 4.31 for male and 5.44 for females obtained for the concurrent positive control, HCA, showed greater than a three-fold increase over the control value indicating a clear positive response for this known weak sensitiser that confirmed the reliability of this test procedure.

\section{Conclusion}

The results revealed no significant difference between samples means or variability between the sexes and the SI values observed for both male and female mice of positive control were within the range of historical control data for female mice. These data provide initial support for the use of male mice in the LLNA and will be followed by further experimentation.

\section{References}

[1]. Basketter, D., Ball, N., Cagen, S., Carrilo, J.C., Certa, H., Eigler, D., Garcia, C., Esch, H., Graham, C., Haux, C., Kreiling, R. and Mehling, A. (2009), Application of a weight of evidence approach to assessing discordant sensitisation datasets: implications for REACH, Reg. Toxicol. Pharmacol., 55, 90-96.

[2]. Basketter, D.A., Gerberick, G.F. and Kimber, I. (1998), Strategies for identifying false positive responses in predictive sensitisation tests, Food Chem. Toxicol., 36, 327-33.

[3]. Basketter, D.A., Gerberick, G.F., Kimber, I. and Loveless, S.E. (1996), The local lymph node assay: A viable alternative to currently accepted skin sensitisation tests, Food Chem. Toxicol., 34, 985-997.

[4]. Chamberlain, M. and Basketter, D.A. (1996), The local lymph node assay: status of validation, Food Chem. Toxicol., 34, 999-1002

[5]. Dean, J.H., Twerdok, L.E., Tice, R.R., Sailstad, D.M., Hattan, D.G., Stokes, W.S. (2001), ICCVAM evaluation of the murine local lymph node assay: II. Conclusions and recommendations of an independent scientific peer review panel, Reg. Toxicol. Pharmacol, 34: $258-273$.

[6]. Dearman, R.J., Hilton, J., Evans, P., Harvey, P., Basketter, D.A. and Kimber, I. (1998), Temporal stability of local lymph node assay responses to hexyl cinnamic aldehyde, J. Appl. Toxicol., 18, 281-284.

[7]. Haneke, K.E., Tice, R.R., Carson, B.L., Margolin, B.H., Stokes, W.S. (2001), ICCVAM evaluation of the murine local lymph node assay: III. Data analyses completed by the national toxicology program interagency center for the evaluation of alternative toxicological methods, Reg. Toxicol. Pharmacol, 34, 274-286.

[8]. Hayes, B.B. and Meade, B.J. (1999), Contact sensitivity to selected acrylate compounds in B6C3F1 mice: relative potency, cross reactivity, and comparison of test methods, Drug. Chem. Toxicol., 22, 491-506.

[9]. Hayes, B.B. and Meade, B.J. (1999), Contact sensitivity to selected acrylate compounds in B6C3F1 mice: relative potency, cross reactivity, and comparison of test methods, Drug. Chem. Toxicol., 22, 491-506.

[10]. Hayes, B.B., Gerber, P.C., Griffey, S.S. and Meade, B.J. (1998), Contact hypersensitivity to dicyclohexylcarbodiimide and diisopropylcarbodiimide in female B6C3F1 mice, Drug. Chem. Toxicol., 21, 195-206.

[11]. Homey, B., von Schilling, C., Blumel, J., Schuppe, H.C., Ruzicka, T., Ahr, H.J., Lehmann, P. and Vohr, V.W. (1998), An integrated model for the differentiation of chemical-induced allergic and irritant skin reactions, Toxicol. Appl. Pharmacol., 153, 83-94.

[12]. ICCVAM (2009), ICCVAM Test Method Evaluation Report. Assessment of the Validity of the LLNA for Testing Pesticide Formulations and Other Products, Metals, and Substances in Aqueous Solutions, NIH Publication Number 10-7512, Research Triangle Park, NC: National Institute of Environmental Health Sciences.

[13]. ICCVAM (2009), Recommended Performance Standards: Murine Local Lymph Node Assay, NIH Publication Number 09-7357, Research Triangle Park, NC: National Institute of Environmental Health Sciences. 
[14]. ICCVAM (2009), Report on the ICCVAM-NICEATM/ECVAM/JaCVAM Scientific Workshop on Acute Chemical Safety Testing: Advancing In Vitro Approaches and Humane Endpoints for Systemic Toxicity Evaluations. Research Triangle Park, NC: National Institute of Environmental Health Sciences.

[15]. ICCVAM (2009), The Interagency Coordinating Committee on the Validation of Alternative Methods (ICCVAM) Test Method Evaluation Report. The Reduced Murine Local Lymph Node Assay: An Alternative Test Method Using Fewer Animals to Assess the Allergic Contact Dermatitis Potential of Chemicals and Products, NIH Publication Number 09-6439, Research Triangle Park, NC: National Institute of Environmental Health Sciences.

[16]. ILAR (1996), Institute of Laboratory Animal Research (ILAR) Guide for the Care and Use of Laboratory Animals, 7th ed. Washington, DC: National Academies Press.McGarry, H.F. (2007), The murine local lymph node assay: regulatory and potency considerations under REACH, Toxicol., 238, 71-89.

[17]. Kimber, I. and Basketter, D.A. (1992), The murine local lymph node assay; collaborative studies and new directions: A commentary, Food Chem. Toxicol., 30, 165-169.

[18]. Kimber, I., Dearman, R.J., Betts, C.J., Gerberick, G.F., Ryan, C.A., Kern, P.S., Patlewicz, G.Y. and Basketter, D.A. (2006), The local lymph node assay and skin sensitization: a cut-down screen to reduce animal requirements? Contact Dermatitis, 54, 181-185.

[19]. Kimber, I., Dearman, R.J., Scholes, E.W. and Basketter, D.A. (1994), The local lymph node assay: developments and applications, Toxicol., 93, 13-31.

[20]. Kimber, I., Hilton, J., Dearman, R.J., Gerberick, G.F., Ryan, C.A., Basketter, D.A., Lea, L., House, R.V., Ladies, G.S., Loveless, S.E. and Hastings, K.L. (1998), Assessment of the skin sensitisation potential of topical medicaments using the local lymph node assay: An interlaboratory exercise, J. Toxicol. Environ. Health, 53, 563-79.

[21]. Kreiling, R., Hollnagel, H.M., Hareng, L., Eigler, L., Lee, M.S., Griem, P., Dreessen, B., Kleber, M., Albrecht, A., Garcia, C. and Wendel, A. (2008), Comparison of the skin sensitizing potential of unsaturated compounds as assessed by the murine local lymph node assay (LLNA) and the guinea pig maximization test (GPMT), Food Chem. Toxicol., 46, 1896-1904.

[22]. OECD (1987), Acute Dermal Toxicity, OECD Guideline for Testing of Chemicals No 402, Paris, France.

[23]. OECD (1992), Skin Sensitisation. OECD Guideline for Testing of Chemicals No 406, OECD, Paris.

[24]. OECD (2000), Guidance Document on the Recognition, Assessment and Use of Clinical Signs as Humane Endpoints for Experimental Animals Used in Safety Evaluation, Environmental Health and Safety Monograph, Series on Testing and Assessment No. 19, ENV/JM/MONO(2000)7, OECD, Paris.

[25]. OECD (2002), Acute Dermal Irritation/Corrosion. OECD Guideline for Testing of Chemicals No. 404, Paris, France.

[26]. OECD (2002), Skin Sensitisation: Local Lymph Node Assay. OECD Guideline for the Testing of Chemicals No 429, Paris.

[27]. OECD (2005), Guidance Document on the Validation and International Acceptance of New or Updated Test Methods for Hazard Assessment, Environment, Health and Safety Monograph, Series on Testing and Assessment No. 34, ENV/JM/MONO(2005)14, OECD, Paris.

[28]. Patterson, R.M., Noga, E. and Germolec, D. (2007), Lack of evidence for contact sensitization by Pfiesteria extract, Environ. Health Perspect., 115, 1023-1028.

[29]. Reeder, M.K., Broomhead, Y.L., DiDonato, L. and DeGeorge, G.L. (2007), Use of an enhanced local lymph node assay to correctly classify irritants and false positive substances, Toxicologist, 96, 235.

[30]. Sailstad, D.M., Hattan, D., Hill, R.N., Stokes, W.S. (2001), ICCVAM evaluation of the murine local lymph node assay: I. The ICCVAM review process, Reg. Toxicol. Pharmacol, 34: 249-257.

[31]. Van Och, F.M.M., Slob, W., De Jong, W.H., Vandebriel, R.J. and Van Loveren, H. (2000), A quantitative method for assessing the sensitising potency of low molecular weight chemicals using a local lymph node assay: employment of a regression method that includes determination of uncertainty margins, Toxicol., 146, 49-59.

[32]. Vohr, H.W. and Ahr, H.J. (2005), The local lymph node assay being too sensitive? Arch. Toxicol., 79, 721-728.

[33]. Woolhiser, M.R., Hayes, B.B. and Meade, B.J. (1998), A combined murine local lymph node and irritancy assay to predict sensitization and irritancy potential of chemicals, Toxicol. Meth., 8, 245-256. 